\title{
Some clear policies must be issued to support the internship and practice of full-time professional master
}

\author{
Chen dan $^{1, a}$, Ma yonghong ${ }^{2, b}$ and Zhang le ${ }^{3, c}$ \\ ${ }^{1}$ Beihang University, China \\ ${ }^{2}$ BeihangUniversity, China \\ ${ }^{3}$ BeihangUniversity, China \\ a janedan3@163.com, ${ }^{b}$ janedan3@163.com, ${ }^{c}$ janedan3@163.com
}

Keywords: full-time professional master, internship and practice, policies and regulations. Abstract. The internship and practice is very important for the training process of professionalmaster, as the professional master is a kind of career oriented degree. It is found that the employers attach great importance to the internship experience and practical ability of professional master, and universities, professional masters also have urgent needs for internship and practice experience through the authors' questionnaire survey. However, the policies of professional master practice are not perfect in China. The laws for professional master practice can be improved from the legislative level, the main responsibility, funding and incentive mechanism by vocational education related policies and regulations.

\section{Introduction}

The professional degree of graduate in China established in the early 90's of last century, and the training ability gradually enhance through these more than 20 years ${ }^{[1]}$. According to the academic degrees committee of the State Council, the professional master's degree is a professional degree for cultivating of special high-level professional talents ${ }^{[2]}$. Internship and practice is not only an important part and a key step of the training for professional master, but also a key feature different from the Master of Science in the academic. Therefore, many scholars studied on internship and practice of professional master, and they have made certain achievements. Jianfu Su explored the feasibility of to establish a full-time professional master practice base from the establishment of practice base for necessary conditions, procedures, the rights and obligations, and so on ${ }^{[3]}$; Xiaoli Zhang discussed the industry practice teaching mode and steps, then put forward the methods of technology and industry quality education, practice education and the selection and performance appraisal in the practice of industry model.

In the case of full-time master of education, Wudi analyzed the problems of Colleges, interns and the internship mentor in the practice model, and put forward the strategy of constructing off-campus internship model ${ }_{[5]}$. However; there are few researches on the support policies of professional master's internship and practice. This paper firstly classify the professional master's internship and practice policies, then survey the internship and practice status of professional master by way of questionnaire, analyze the lacks of professional master's internship and practice policies, suggests the government must issue the professional master's internship and practice policies as vocational education in order to guarantee the professional master's internship and practice to implement.

\section{Policies of professional master's internship and practice policies in China}

There are mainly two resources of professional master internship and practice policies in China: the one is administrative regulations and rules, such as "Opinions about strengthening and improving the professional degree education" (the Academic Degrees Committee of the State Council, Ministry of education, degree), “The education Ministry's opinions about doing well in full-time professional degree graduate training"," Opinions about deepening the graduate students education reforming "(Ministry of education, the national development and Reform Commission, Ministry of finance, teaching and research.These policies only emphasize the importance of master of 
professional internship and practice, and require promoting cooperation between school and enterprise, and they have no clear rules about how to establish the internship and practice base and what are the supporting and guarantee mechanisms. The second followed the internship and practice policies of vocational education, such as the State Administration of Taxation "enterprise pay intern compensation tax deduction management approach" clearly stipulates: the internship reward can be deducted from enterprise income tax base that signed cooperation agreement more than three years with high education school. However, in actual, this policy is seldom used as its strict condition and tedious.

Now, there are no special policies about internship and practice base, funding sources, internship instructor subsidies for professional master. And various provinces also do not formulate specific measures of master of professional practice.

\section{Data and Analysis}

There are some data about internship and practice of full-time professional master. The employers are 235 , the school administrators and the tutors are 153, and the full-time professional masters are 1830.

Table 1 The employers' attitudes to the internship and practice of full-time professional master

\begin{tabular}{|c|c|c|c|c|}
\hline Number & $\begin{array}{l}\text { Questions (multiple } \\
\text { choices) }\end{array}$ & Answers & Proportion & Rank \\
\hline \multirow{2}{*}{1} & \multirow{2}{*}{$\begin{array}{l}\text { How to choose a } \\
\text { recruitment fixed school }\end{array}$} & Satisfaction to the internship master & $46 \%$ & $2($ Total 7$)$ \\
\hline & & $\begin{array}{l}\text { Records of past employment or } \\
\text { internship }\end{array}$ & $32 \%$ & $3($ Total 7) \\
\hline 2 & $\begin{array}{l}\text { Master basic conditions for } \\
\text { recruitment }\end{array}$ & Internship and practice experience & $77 \%$ & $2($ Total 5) \\
\hline \multirow{2}{*}{3} & \multirow{2}{*}{$\begin{array}{l}\text { Hiring five master's most } \\
\text { prized ability }\end{array}$} & Professional knowledge & $74 \%$ & 1 (Total 16) \\
\hline & & Professional practice ability & $41 \%$ & $4($ Total 16) \\
\hline 4 & $\begin{array}{l}\text { Master should improve the } \\
\text { ability }\end{array}$ & Professional practice ability & $30 \%$ & 3(Total 16) \\
\hline \multirow{3}{*}{5} & \multirow{3}{*}{$\begin{array}{l}\text { Think the universities } \\
\text { should be improved }\end{array}$} & Practice opportunities & $75 \%$ & 1 (Total 9) \\
\hline & & In collaboration with industry & $46 \%$ & $2($ Total 9) \\
\hline & & $\begin{array}{l}\text { Cultivating students' understanding of } \\
\text { the industry professional }\end{array}$ & $44 \%$ & 3 (Total 9) \\
\hline
\end{tabular}

Table 1 is the attitude of the employers to the internship and practice of full-time professional master. It shows that the employers focus on the master's internship and practice experiences and practice ability(in the terms of employment, internship and practice experiences accounted $77 \%$, ranked 2; the most important five capabilities, the professional practice ability accounted $41 \%$,ranked 4.) At the same, they suggested that the master must improve the internship and practice ability( In the terms of , internship and practice ability ranked 3.), and high education school should strengthen cooperation with industries and enterprises in order to provide more internship and practice chances to masters(the practice chance ranked 1 ). But in this research, only $27 \%$ of the employers establish a cooperative training base for full-time professional master with school. 
Table 2 Attitudes of school administrators and instructors to the practice of full-time professional master

\begin{tabular}{|c|l|l|c|l|}
\hline Number & \multicolumn{1}{|c|}{ Questions (multiple choices) } & \multicolumn{1}{|c|}{ Answers } & Proportion & \multicolumn{1}{|c|}{ Rank } \\
\hline \multirow{2}{*}{1} & \multirow{2}{*}{ the urgent improved aspects of professional master } & the practice course & $65 \%$ & 1 (Total 9) \\
\cline { 3 - 5 } & the practice place & $44 \%$ & 3 (Total 11) \\
\hline 2 & the choice of practice base & by school & $58 \%$ & 1 (Total 4) \\
\cline { 3 - 5 } & by himself & $35 \%$ & 2 (Total 4) \\
\hline 3 & $\begin{array}{l}\text { the promotion of practice chance what school } \\
\text { provides }\end{array}$ & lower than 50\% & $39 \%$ & \\
\cline { 3 - 6 } & $\begin{array}{l}\text { the difficulty of improving the training quality of } \\
\text { full-time professional master }\end{array}$ & the practice place & $33 \%$ & 1 (Total 6) \\
\hline 5 & $\begin{array}{l}\text { shortcomings of training process of full-time } \\
\text { professional master }\end{array}$ & practice course & $63 \%$ & 1 (Total 11) \\
\cline { 3 - 6 } & the practice place & $38 \%$ & 2 (Total 11) \\
\hline
\end{tabular}

Table 2 shows the attitude of the school administrators and instructors for full-time professional master's internship and practice. From Table 2, we can know that school administrators and teachers generally considered the difficulty of improving the professional master training quality is arranging practice base.(accounted for 33\%,ranked 1). The most urgency of full-time professional master is to implement the internship and practice (practical teaching content of the course accounted for $63 \%$, ranked 1 ; the implementation of practice base accounted 38\%, ranked 2).

Table 3 the attitude of full-time professional master to internship and practice

\begin{tabular}{|c|c|c|c|c|}
\hline$\underset{r}{\text { Numbe }}$ & Questions (multiple choices) & Answers & Proportion & Rank \\
\hline \multirow[t]{2}{*}{1} & \multirow{2}{*}{$\begin{array}{l}\text { the training quality of professional } \\
\text { master (total 11) }\end{array}$} & $\begin{array}{l}\text { cooperation employers or industry } \\
\text { staff engagement }\end{array}$ & 3.87 & 11 \\
\hline & & practice process & 3.92 & 9 \\
\hline \multirow{3}{*}{2} & \multirow{3}{*}{$\begin{array}{l}\text { what needed strengthen and improve } \\
\text { (total 11) }\end{array}$} & practice course & $47 \%$ & 1 \\
\hline & & internship and practice experience & $42 \%$ & 2 \\
\hline & & communicate with industry & $32 \%$ & 3 \\
\hline \multirow{3}{*}{3} & \multirow{3}{*}{$\begin{array}{l}\text { communication with the internship } \\
\text { place (total 6) }\end{array}$} & do not take in the internship & $29 \%$ & 1 \\
\hline & & by himself & $24 \%$ & 2 \\
\hline & & $\begin{array}{l}\text { the practice place of school communicate or } \\
\text { arrange }\end{array}$ & $12 \%$ & 5 \\
\hline 4 & most needed help (total 6) & employment internship & $22 \%$ & 1 \\
\hline \multirow[b]{2}{*}{5} & \multirow{2}{*}{$\begin{array}{l}\text { satisfaction with practice process } \\
\text { (total 7) }\end{array}$} & internship and practice subsidies & 3.36 & 7 \\
\hline & & $\begin{array}{l}\text { intership and practice place } \\
\text { management }\end{array}$ & 3.65 & 6 \\
\hline \multirow{2}{*}{6} & \multirow{2}{*}{ internship subsides } & no & $42 \%$ & \\
\hline & & few & $24 \%$ & \\
\hline
\end{tabular}


Table 3 is the attitude of full-time professional master to internship and practice. From table 3 we can see that the professional masters generally believed that internship and practice is the weakness of professional master training process(In the professional master training quality evaluation, "practice" ranked 9; the professional degree should be strengthened and improved, "teaching content", "internship experience", "cooperation with industry" ranked 1, 2, 3).At the same time, they most want to get help of employment train(ranked 1), and the most dissatisfaction are practice subsidies and internship and practice place management(ranked the last 1 and last 2).

Through the research, we can know the employers, school administrators and instructor, full-time professional masters think that internship and practice is the key course of improving the professional master training quality, also is the difficulty and weakness. Especially, the internship and practice base and the subsidies must be focused on.

\section{Suggestions}

The internship and practice of full-time professional master is a systematic project. It includes policy legislation, management, mechanism design, security incentives and so on. In order to realize the professional master internship and practice and improve the professional master training quality, the government should focus on top-level design and strengthen the professional internship and practice policy legislation.

Like vocational education, the orientation of professional master training is employment and focusing on the production, study and research in the aspect of vocation and practical training.

Now, the policies of vocational education are relatively complement. In view of the shortcomings, the government can learn from the relevant practice of vocational education, and strengthen the internship and practice policy legislation.

Construct a multi-level, integrated policies system. Now, vocational education has many levels and complete policies and regulations from the central government to the provinces and cities, laws and regulations and regulations. "Chinese vocational education law" (1995) specific the vocation education status and development direction in view of the national legal perspective. "Decision of the State Council on the development of occupation education" (GuoFa〔2002) No. 16), "The opinions of accelerating the development of modern vocation education of the State Council(GuoFa (2014) No. 9), "The opinions on further strengthening high skilled talents of the general office of the CPC Central Committee and the general office of the State Council'(No.

(2006) and No. 15) said to develop vigorously the vocation education. "Several opinions on improving the teaching quality of Higher Vocational Education of Education department"(Higher Education (2006) No. 16), on behalf of the department regulations to improve the occupation education quality views. A number of provinces and cities nationwide formulate the specific policies of implement the school and enterprise cooperation and strengthening internship and practice of vocation education.

Conversely, in view of law level, there are only policies of the State Council; Ministry of education and the provinces has not issue specific ways to implement the internship and practice of professional master. In view of the legal order, there are only departmental regulations, no law. So in practice, the implementation of the policy effect is limited. According to the latest revision of the 2015 "legislative law", China's system of laws and regulations comprises the laws, administrative regulations, local regulations, autonomous regulations, separate regulations, State Council administrative rules and local government regulations in accordance with the law effect comprises . The professional master internship and practice policies must be constructed a multi-level, completed system concluded from law to local government regulations to guarantee the implement the internship and practice of professional master refer to the practice of vocational education.

Clear the main responsibility of the parties to the practice of the practice. The laws related to vocational education clearly stipulates that practice subject, including government, enterprises, schools, industry , and so on.. "The State Council on vigorously develop vocational education decision" (GuoFa〔2002) No. 16) pointed out that the government, enterprise, industry and social 
must take charge for the vocational education[6].The government leads, the enterprise are relied, the industry take part in well. Specific measures for implementation of some provinces and cities also defined the responsibility of the main parties in the practice of practice, such as "Notice of promoting vocational education in Henan Province school enterprise cooperation (for Trial Implementation)" (Yu Zheng (2012) No. 48), "The regulation of Ningbo City school and enterprise cooperation in Vocational Education"pointed out that to promote school and enterprise cooperation in vocational education is the common responsibility of the government, vocational colleges and Industry Association (Organization), the enterprise .

The internship and practice of professional master related to the government, enterprise, school and students. So the relatively policies must clearly specific the responsibilities of the parties, and build clear responsibility and benefit sharing platform and mechanism, in order to stimulate the parties involved in the practice of enthusiasm.

Establishing the fund guarantee mechanism of practice. The funding of practice is an important guarantee for the implementation of practice. A series of central policy, such as "The decision of vigorously developing vocational education of the State Council on" (GuoFa (2005) No. 35), "The opinions of strengthening high skilled talents of the general office of the CPC Central Committee and the general office of the State Council "(Ban Fa〔2006) No. 15) all suggested that the central government should arrant special funds for vocational education, and through award replacing subsides to guide and support for the construction of trainmen base. Some provinces ruled that on one hand, government coordinates the relevant funds support school enterprise cooperation in vocational education development. On the other hand, finance departments should improve financial services, and build up the cooperation credit business between schools and enterprises, and give priority to loans for enterprises which meet the loan conditions of the cooperation project.

Master of professional internship and practice funds are from school. In order to reflect the responsibility of the main parties, the government should formulate relevant policies, and use finance to attract social capital, and arrange the master of professional practice funding sources multi-channel.

Complete the practice incentive measures. The provinces issued a series of policies for the vocational education practice incentives, such as the "issued by Henan province to promote school enterprise cooperation to promote the occupation education measures (Trial) Notice" (Henan political [2012]48), "Jiangsu province implementation of the" PRC law "rules" occupation education (revised 1999 through September 2010.) specific: Employers can suit to the welfare undertaking and preferential tax policies who establish the internship and practice base. Internship rewards can be deducted from enterprise income tax base; the scholarship, grants for student can included in the enterprise education and training funds as business expense and be suit to the tax policy. To subside the teacher who teach the internship student; To help the college to buy accident insurance; For 3 months or above students, the internship rewards are higher than $80 \%$ of the annual local minimum wage workers; To reward the collective and individual who make outstanding contributions in process of cooperation with school and staff training and education.

The internship and practice of professional master also can test the vocational education practice. The provinces can formulate clear policies to incentive the employers who take part in the professional master cooperation via material and spirit to improve the employers'enthusiasm and pride sense

\section{Conclusions}

In order to promote the higher quality employment of graduates, the State Council promulgated the "implementation opinions of the general office of the State Council on deepening the higher education innovation and entrepreneurship education reform" ( (2015) , No. 36).It pointed out there are some shortcomings in higher education, such as the concepts of innovation lags behind, education is not tight with professional education and practice. And it encourage all regions and universities make full use of various resources to the construct the entrepreneurship education 
practice platform, improve the national, local and university three level of innovation and entrepreneurship training teaching system; improve the system of innovation and entrepreneurship, financial support and policy support, funding channels, use of social capital, leading and support for college students innovation and entrepreneurship.

Professional masters are the high-level professional talent who can speed up the economic construction and meet social development needs. They are the precious human capitals who promote the enterprise innovation and achieve national innovation driven strategy. For improving the quality of master of professional, the government should now take the chance of higher education innovation and entrepreneurship, and complete the professional master intern-ship and practice policies system, security practice sources of funds, promote the practice of plat-form construction, formulate practice incentives, to ensure the implementation of the master of professional practice.

\section{References}

[1] Ma Yonghong, Zhang Le, Zhang Zhixiang.A Comparative Study of International Practices in Granting Professional Degrees (in Chinese).Journal of National Academy of Education Administration, 2014, (8): 89-94.

[2] Ministry of Education. Some opinions on strengthening and improving the professional degree education.Degree and graduate education,2002, (2): 74-75.

[3] Su Jianfu, Yu Baokun. Research on the construction of full time professional master's practice base (in Chinese).SCIENCE \& TECHNOLOGY INFORMATION,2011, (22): 228.

[4] ZHANG Xiaoli, ZHANG Kejun, LIU Xin, SUN Xinhua.On New Teaching Model of Professional Practice for Graduate (in Chinese). RESEARCH AND EXPLORATION IN LABORATORY, 2014, 33(1): 225-228.

[5] $\mathrm{Wu}$ Di. Study on the full-time Master of education practice mode (in Chinese). HEILONGJIANG EDUCATION(Higher Education Research \& Appraisal), 2014, (10): 64-66.

[6] The State Council. Decision of the State Council on vigorously developing vocational education.,ZHONGGUO ZHIYE JIAOYU, 2005, (217): 6-9. 